\title{
Erratum to: Nimbolide a limonoid from Azadirachta indica inhibits proliferation and induces apoptosis of human choriocarcinoma (BeWo) cells
}

\author{
G. Harish Kumar • K. V. P. Chandra Mohan • \\ A. Jagannadha Rao $\cdot$ S. Nagini
}

Published online: 27 April 2012

(C) Springer Science+Business Media, LLC 2012

\section{Erratum to: Invest New Drugs 2009; 27: 246-252 \\ DOI 10.1007/s10637-008-9170-z}

In the third paragraph of Introduction section, the following words should have been deleted: "(5,7,4'-trihydroxy-3',5'diprenylflavanone)". Paragraph should read as below:

Azadirachta indica A. Juss, commonly known as neem, elaborates a vast array of bioactive phytochemicals that exhibit potent medicinal properties [11]. Although all parts of the neem tree are recognized to confer health benefits, the medicinal utilities for neem leaf are more wide ranging and include immunomodulatory, antiinflammatory, antioxidant, antimutagenic, and anticarcinogenic effects [12]. In previous reports from this laboratory, we have demonstrated that the chemopreventive effects of ethanolic neem leaf extract against experimental oral and gastric carcinogenesis are mediated by modulation of xenobiotic-metabolising enzymes, upregulation of antioxidants, inhibition of cell proliferation and induction of apoptosis [13-15]. Recently, we identified nimbolide, a limonoid, as one of the major constituents in neem leaf fractions by highperformance liquid chromatography [16]. Although nimbolide was shown to exert cytotoxicity against a panel of cancer cell lines, the effect of nimbolide on markers of cell proliferation and apoptosis has not been investigated [17-19].

The online version of the original article can be found at http://dx.doi.org/ 10.1007/s10637-008-9170-z.

G. Harish Kumar · K. V. P. Chandra Mohan · S. Nagini $(\bowtie)$

Department of Biochemistry and Biotechnology,

Faculty of Science, Annamalai University,

Annamalainagar 608002 Tamil Nadu, India

e-mail: s_nagini@yahoo.com

A. Jagannadha Rao

Department of Biochemistry, Indian Institute of Science,

Bangalore 560 012, India 